Ann. Nutr. Metab. 1982;26:I-VI

\title{
Contents, Vol. 26, 1982
}

\section{Annals of}

Nutrition \& Metabolism

European Journal of Nutrition, Metabolic Diseases and Dietetics Journal européen de nutrition, des maladies métaboliques et de diététique Europäische Zeitschrift fttr Ernährungswissenschaft, Stoffwechselstörungen und Diätetik

Annals of Nutrition and Metabolism (formerly 'Annales de la Nutrition et de ГAlimentation' and 'Nutrition and Metabolism') is recognised by the 'Federation of European Nutrition Societies' (FENS) as its official journal

Founded 1959 as 'Nutritio et Dieta' by E. Azerad, H. Kapp

and J. Trémolières

Former Main Editor: A. Wretlind (1961-1969)

Main Editor

N. Zöllner, München

Associate Editors

E.M. Widdowson, Cambridge G. Debry, Nancy

Executive Editor

G. Wolfram, Freising

Editorial Board

L.G. Alcindor, Paris

B. Brubacher, Basel

J.W.T. Dickerson, Guildford

P. Fábry $\uparrow$, Praha

F. Falkner, Berkeley, Calif.

Ch. Frayssinet, Villejuif

L. Gueguen, Jouy-en-Josas

L. Hambraeus, Uppsala

K. Hellström, Stockholm

S. Heyden, Durham, N.C.

F.A. Hommes, Augusta, Ga.

B. Jacotot, Créteil

D.E.M. Lawson, Cambridge

I. Macdonald, London H.K.. Mangold, Münster C.F. Mills, Aberdeen D.J. Naismith, London

K.R. Norum, Oslo G. Schlierf, Heidelberg D.H. Shmerling, Zurich M.A. Spadoni, Roma A.J.

Vergroesen,

Vlaardingen-Duiven A. Wretlind, Stockholm H. Zucker, München

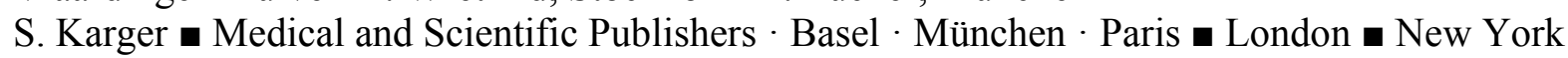

- Tokyo $\cdot$ Sydney

Drug Dosage 
The authors and the publisher have exerted every effort to ensure that drug selection and dosage set forth in this text are in accord with current recommendations and practice at the time of publication. However, in view of ongoing research, changes in government regulations, and the constant flow of information relating to drug therapy and drug reactions, the reader is urged to check the package insert for each drug for any change in indications and dosage and for added warnings and precautions. This is particularly important when the recommended agent is a new and/or infrequently employed drug.

All rights reserved.

No part of this publication may be translated into other languages, reproduced or utilized in any form or by any means, electronic or mechanical, including photocopying, recording,

microcopying, or by any information storage and retrieval system, without permission in writing from the publisher.

S. Karger AG, P.O. Box, CH-4009 Basel (Switzerland) Printed in Switzerland by Thür AG Offsetdruck, Pratteln

Contents Vol. 26,1982

No. 1 Studies of the Effects of Cholecalciferol Upon the Metabolism of Rachitic Chick Growth Cartilage

Dickson, I.R.; Kodicek, E 1

Hepatic Free Choline and Betaine and the Utilization of Dietary Protein in the Choline-

Deficient Rat

Arvidson, G.A.E.; Asp, N.-G 12

Carbohydrate Conservation in the Obese: a Theory to Explain the Ease of Weight Gain

Naismith, D.J.; Holdsworth, M.D.; Bailey, J.L.; Hewitt, A.P.; Emery, P.W 18

Modifications de $\Gamma$ amino-acidémie des cirrhotiques sous l'influence de sels d'ornithine

Molimard, R.; Charpentier, C; Lemonnier, F 25

Effects of Prior Fasting and of Glucose Availability on Fatty-Acid-Induced Increases in

Oxygen Consumption in the Rat Perfused Liver

Bradley, J.R.; Macdonald, LA 37

Comparative Effects of Soy and Casein Protein on Plasma Cholesterol Concentrations

Raheja, K.L.; Linscheer, W.G 44

Konzentrationen verschiedener Stoffwechselmetaboliten im experimentellen Bleimangel

Kirchgessner, M.; Reichlmayr-Lais, A.M 50

Serum Concentrations Lp(a) and Other Lipoprotein Parameters in Heavy Alcohol Consumers

Marth, E.; Cazzolato, G.; Bittolo Bon, G.; Avogaro, P.; Kostner, G.M 56

Treatment of Magnesium Deficiency After Intestinal Bypass for Obesity

Hessov, I.; Berg, V.; Holm, C.N.; King, R.F.G.J 63

Different Effects of Various Carbohydrates on the Metabolic Rate in Rats

Sharief, N.; Macdonald, $1 \quad 66$

No. 2 Further Considerations on Alcohol Intake and Coronary Risk Factors in a Rome Working Population Group: HDL-Cholesterol

Angelico, F.; Bucci, A.; Capocaccia, R.; Morisi, G.; Terzino, M.; Ricci, G 73

Removal and Addition of Bile in the Intestine, and Pancreatic Colipase Activity in the Pig:

Effect of a High-Lipid Diet

Corring, T.; Mourot, J.; Charles, M.; Léger, C

Absorptionsveränderungen von Mangan während Gravidität und Laktation

Kirchgessner, M.; Sherif, Y.S.; Schwarz, F.J 83 
Estimating Sodium Intake from Food Consumption Data

Pietinen, $\mathrm{P} \quad 90$

The Skeleton, an Important Site of Lipogenesis in the Chick

Nir, I.; Lin, H 100

Circadian Metabolic Rhythms in Obese Children

Desjeux, J.-F.; Gernez-Lestradet, C; Deschamps, I.; Machinot, S.; Rolland, F.; Lestra-

det, $\mathrm{H} 106$

IV Contents

Alteration in Fatty Acid Composition of Neurons, Astrocytes, Oligodendrocytes, Myelin and Synaptosomes in Intrauterine Malnutrition in Rat

Morand, O.; Chanez, C; Masson, M.; Dumont, O.; Flexor, M.A.; Baumann, N.; Bourre, J.M 111

Growth, Food Intake, Motor Activity and Experimental Cardiac Necrosis in Early Malnour ished Male Rats

Pafizková, J.; Faltová, E.; Mráz, M.; §pátová, M 121

Circadian Feeding Pattern in Pregnant Rats Fed Three Levels of Protein

Hitier, Y.; Champigny, O.; Homayoon, P.; Bourdel, G

Effects of Plant Proteins on Cholesterol Metabolism in Growing Rats Fed Atherogenic

Diets

Mokady, S.; Liener, I.E 138

No. 3 In-vitro-Messungen zum Vitamin-B $3 / 8$-Fluss Serosa $\rightarrow$ Mucosa bei verschiedenen Pyridoxin $\cdot$ HCl-Konzentrationen der Serosalösung

Kirchgessner, M.; Roth-Maier, D.A.; Zinner, P.M 145

Effects of Exogenous Glucagon on Concentrations of Glucose, Fructose and Insulin in

Plasma of Sheep Fetus

Schreiner, R.L.; Lemons, J.A.; Moorehead, H.; Bohnke, R.; Reyman, D 152

Incorporation of Dietary 1-0-Alkyldiacyl Glycerols into Tissue Lipids of Neonatal Rats

Ahrné, L.; Björck, L.; Claesson, 0162

Effects of Vitamin E on Mixed Lymphocyte Cultures

Davey, F.R.; Dock, N.L 171

Postprandial Plasma Zinc Changes in Pigs

Lantzsch, H.-J.; Berschauer, F 178

Fluorometry of Selenium in Human Hair, Urine and Blood. A Single-Tube Process for

Submicrogram Determination of Selenium

Chen, S.Y.; Collipp, P.J.; Boasi, L.H.; Isenschmid, D.S.; Verolla, R.J.; San Roman, G.A.;

Yen, J.K 186

Peripheral Metabolism of Thyroid Hormones in Vitamin A-Deficient Rats

Higueret, P.; Garcin, H 191

Vitamin B6 Deficiency as Related to Oxalate-Synthesizing Enzymes in Growing Rats

Murthy, M.S.R.; Talwar, H.S.; Thind, S.K.; Nath, R 201

No. 4 Serum Vitamin BI2 and Blood Cell Values in Vegetarians

Dong, A.; Scott, S.C 209

Cholesterol Synthesis in the Liver, Kidneys and Brain after Injection of Uniformly 14C-

Labeled Oleic or Linoleic Acid to Developing Rats

Carreau, J.P.; Lapous, D.; Raulin, J 217

Effect of Dietary Restriction with and without Excess Leucine on Hepatic Tryptophan Oxy- 
genase, 3-Hydroxyanthranilate Oxygenase and Leucine Aminotransferase in Rats Shanker, V.; Chugh, K.; Lai, H.; Saini, A.S 227

Physiological Effects of Varying Dietary Linoleic Acid in Spontaneously Hypertensive Rats

Mogenson, G.J.; Box, B.M 232

Use of Fibroblast Culture to Diagnose and Genotype Familial Hypercholesterolaemia

Spengel, F.A.;Harders-Spengel, K.M.;Keller, C.F.;Wieczorek, A.;Wolfram, G.;Zöllner, N. 240

Effects of Prenatal Malnutrition on Development of Oral Tissue in Neonatal Rats

Winkler, M.M.; Nakamoto, T 248

Contents

$\mathrm{V}$

A Model of L(+)-Lactate Metabolism in Normal Man

Connor, H.; Woods, H.F.; Ledingham, J.G.G.; Murray, J.D 254

Effects of Fasting and Subsequent Feeding of a Complete or Tryptophan-Free Diet on the Activity of DNA-Synthesizing Enzymes and Protein Synthesis in Gastric Mucosa of

Rats

Majumdar, A.P.N 264

No. 5 Vitamin E and Lipogenesis in the Mammalian Liver

Candlish, J 273

Lack of Induction of VLDL Apoprotein Synthesis by Medium Chain Fatty Acids in the Isolated Rat Liver

Petit, D.; Raisonnier, A.; Amit, N.; Infante, R

Zinc Deficiency: Improvement in Growth and Growth Hormone Levels with Oral Zinc

Therapy

Collipp, P.J.; Castro-Magana, M.; Petrovic, M.; Thomas, J.; Cheruvanky, T.; Chen,

S.-Y.; Sussman, H 287

Trehalase Deficiency. Prevalence and Relation to Single-Cell Protein Food

Bergoz, R.; Vallotton, M.-C; Loizeau, E 291

Effect of Excess Leucine on Tryptophan Oxygenase, 3-Hydroxyanthranilate Oxygenase and

Leucine Aminotransferase in Livers of Young Rats

Chugh, K.; Shanker, V.; Lai, H.; Saini, A.S 296

Comparative Effects of Semisynthetic D-5-Vinyl-2-Thiooxazolidone and Water-Extracted

Rapeseed Meal in the Rat

Ballester, D.; Vera, P.; King, J.; Brunser, O.; Yañez, E 301

Utilization of $\mathrm{L}(+)$ Lactate in Patients with Liver Disease

Connor, H.; Woods, H.F.; Murray, J.D.; Ledingham, J.G.G 308

Prostaglandin Formation in Man during Intake of Different Amounts of Linoleic Acid in

Formula Diets

Adam, O.; Wolfram, G.; Zöllner, N 315

Effect of Vitamin B $3 / 8$ and Bi Deficiencies on the Intestinal Uptake of Calcium, Zinc and

Cadmium

Prasad, R.; Lyall, V.; Nath, R 324

Alterations in Intestinal Function in Response to Thyroxine and Cortisone Administration in Undernourished Rats

Pathak, R.M.; Dudeja, P.K.; Ansari, S.; Mahmood, A

No. 6 Characterization and Nutritional Significance of Peptide Transport in Man 
Silk, D.B.A.; Hegarty, J.E.; Fairclough, P.D.; Clark, M.L 337

Limiting Amino Acids in Bengal Gram (Cicer arietinum) as Determined from Blood Amino Acid Levels and Amino Acid Supplementation Studies in the Rat

Khader, V.; Rao, S.V 353

Energy Cost of Some Common Physical Activities of Chinese Schoolboys

Banerjee, B.; Saha, N 360

Effect of Folate Deficiency on Vitamin B|2 Absorption

Cattan, D.; Belaiche, J.; Zittoun, J.; Yvart, J 367

Metabolic Effects Produced in Baboons Associated with the Ingestion of Diets Based on

Lactose Hydrolysate

Williams, C.A.; Macdonald, 1

VI Contents

Lipoprotein and Blood Pressure Changes during Weight Reduction at Duke's Dietary Reha bilitation Clinic

Nelius, S.J.; Heyden, S.; Hansen, J.P.; Muhlbaier, L.H.; Morris, M 384

Effect of Dietary Protein and Lipid on the Activity of Hepatic Mixed-Function Oxidase

System in Young and Adult Rats

Antal, M.; Nagy, K.; Bedö, M.B 393

Obituary

Pavel Fábry, 1925-1982 400

Erratum 401

Author Index 403

Subject Index 405

Suppl. $1 \quad$ Nutrition and Health. A Survey of Young Men and Women in Heidelberg

L. Arab, B. Schellenberg and G. Schlierf

with the assistance of M. Blum, R. Geiss, B. Heinrich, W. Hemler, A. Holch, M. Kohlmeier, R.

Mordasini, H. Muchowski, J. Oster, P. Oster, G. Vogel and I. Wankmüller, Heidelberg

Please note that contributing subjects to supplement 1, 1982 are listed in a separate subject index. 